\title{
A Continuous-Flow, Two-Step, Metal-Free Process for the Synthesis of Differently Substituted Chiral 1,2-Diamino Derivatives
}

\author{
Margherita Pirola \\ Maria Elena Compostella \\ Laura Raimondi \\ Alessandra Puglisi \\ Maurizio Benaglia*(1) \\ Dipartimento di Chimica, Università degli Studi di Milano, \\ Via Golgi, 19, 20133 Milano, Italy \\ maurizio.benaglia@unimi.it
}

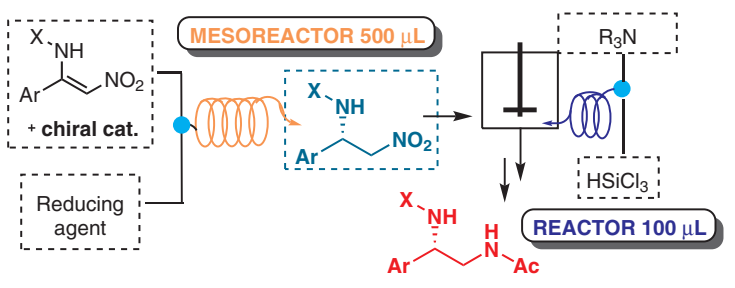

Based on our previous experiences both with dihydropyridine derivatives ${ }^{6}$ and with $\mathrm{HSiCl}_{3}{ }^{7}$ in the organocatalytic synthesis of chiral fluorinated amines, we decided to assess the possibility to perform the nitroenamine reduction under continuous-flow conditions. ${ }^{8}$ We compared the efficiency of both catalytic strategies, through a preliminary screening with a $10-\mu \mathrm{L}$ microreactor, to establish the best reaction conditions, and then we studied a first scale-up of the reduction in a $0.5-\mathrm{mL}$ mesoreactor. The in-flow nitro reduction was also studied and successfully accomplished by two methods, a Raney Ni catalyzed hydrogenation and a metal-free reduction, with the final aim to develop a twostep, continuous-flow process for the stereoselective catalytic synthesis of chiral, differently functionalized 1,2-diamines [Scheme $1(b)]$.

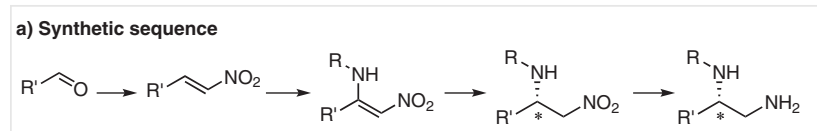

b) Catalytic, stereoselective in-flow reactions

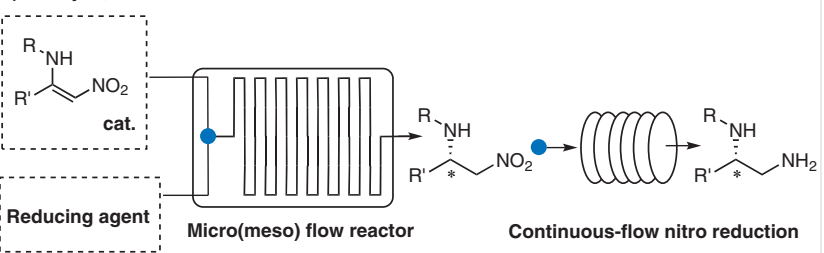

Scheme 1 Continuous-flow, stereoselective two-step synthesis of enantiopure, differently functionalized 1,2-diamines

First, we studied the trichlorosilane-promoted reduction of $N$-PMP nitroenamines (Scheme 2); ${ }^{9}$ as far as we know, the only work in the field was reported by Sun and co-workers, ${ }^{3}$ and required the use of a bifunctional enantiopure sulfoxide as catalyst. We decided to take advantage of 
an easy-to-synthesize, very active catalyst $\mathbf{A}$, recently reported by our group, ${ }^{10}$ and performed some preliminary reductions in batch (Scheme 2).
We were pleased to find that the $N$-picolyl-imidazolidinone $\mathbf{A}$ efficiently promoted the reduction of the model nitroenamine 1, to afford the expected 2-nitro amine $\mathbf{2}$ at

\section{Biographical Sketches \\ Margherita Pirola was born in Milan in 1992. After she took her master degree in chemical science at University of Milan in 2016, she won a six-month fel- lowship as a promising young \\ researcher at the same Universi- ty. She is currently doing her Ph.D. under the supervision of Prof. Maurizio Benaglia, working on the development of uncon- ventional activation strategies}
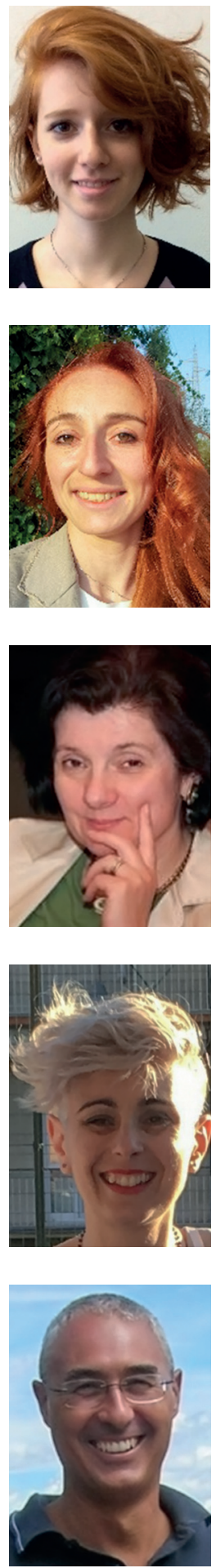

Alessandra Puglisi received her Ph.D. from University of Milan, Italy in 2003. She spent her post-doctoral fellowship in the group of Prof. Amir H. Hoveyda (Boston College, USA) in 2004.

\section{Maria Elena Compostella} graduated with honors in pharmaceutical chemistry and technology in 2012 and holds a Ph.D. degree in bioscience and biotechnology from the Univer-

Laura Raimondi received her Ph.D. in chemistry from the University of Milano in 1989, and joined Prof. Ken N. Houk group at UCLA (Los Angeles, USA). She became Assistant Professor in

Maurizio Benaglia obtained his Ph.D. with Profs. M. Cinquini and F. Cozzi, and then, in 1995, joined he group of Prof. J. S. Siegel at UCSD (USA); in 1998 he moved back to the University of Milan, where in 2015 he was ap- sity of Padua. Her recent research activity is focused on organic catalysis (synthesis and characterization of stereoselective catalysts) and synthesis of fluorinated markers for biologi- the University of Milan in 1990, and Associate Professor in 1998. Experimental and theoretical studies on the origin of stereoselection in organic reactions are her main research field. She
In 2011 she became Assistant Professor at the University of Milan. Her main scientific interests are in the field of stereoselective organocatalysis, in particular, the synthesis, charac- pointed as Full Professor of Organic Chemistry. His research activities focus on the development of novel synthetic methodologies, design of new chiral organocatalysts, study of stereoselective reactions in flow and and transformation of nitro derivatives and on the synthesis of chiral active pharmaceutical compounds. cal tests. Her main scientific interests concern characterization of new pharmacological targets and development of stereoselective catalysts relevant also for biochemical processes. is also interested in the study of intermolecular interactions and in conformational analysis of biomolecules. terization, and synthetic applications of chiral supported catalysts and their applications in continuous-flow chemistry and 3D printing applications. in catalytic reactors, synthesis of pharmaceutical products, taking advantage also of 3Dprinting technologies, and alternative reaction media. 
$0{ }^{\circ} \mathrm{C}$ in quantitative yield and $62 \%$ ee. Simply lowering the temperature to $-40{ }^{\circ} \mathrm{C}$, it is possible to isolate the product in 95\% yield and 94\% ee. Unfortunately, when we performed the reaction under continuous-flow conditions, the product was obtained with high stereoselectivity but low yields. ${ }^{11}$

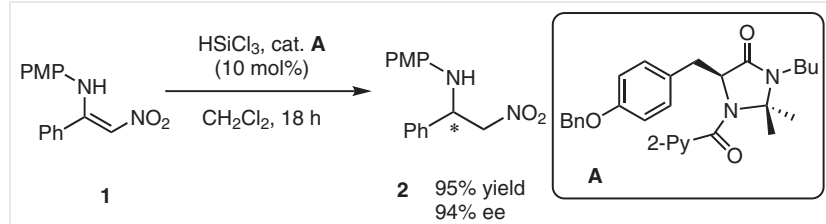

Scheme 2 Trichlorosilane-mediated reduction of nitroenamines

Therefore, we turned our attention to the enantioselective reduction developed by Bernardi and Fochi, that relies on the use of a bifunctional, thiourea-based organocatalyst B (Scheme 3). ${ }^{4}$ We initially studied the feasibility of the method in a continuous-flow process by screening some experimental conditions in a commercially available Chemtrix Labtrix ${ }^{\circledR}$ Start Standard platform that can be used at temperatures ranging from $-20{ }^{\circ} \mathrm{C}$ to $195{ }^{\circ} \mathrm{C}$ and under pressures up to 25 bar. The results are reported in Table 1.

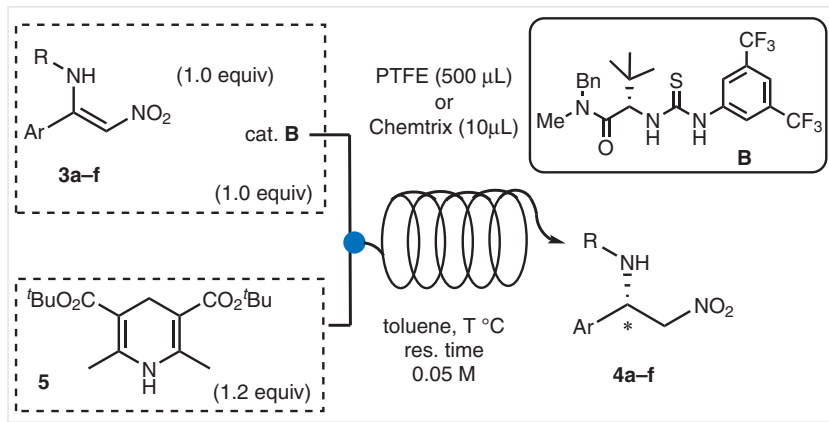

Scheme 3 Enantioselective organocatalytic reduction of $\mathrm{N}$-Boc- or $\mathrm{N}$-Ac-protected nitroenamines
By using a 10- $\mu \mathrm{L}$ microreactor, the few selected results in Table 1 clearly show that the reduction of $\mathrm{N}$-Boc-protected nitroenamine 3a can be efficiently performed in continuo, with short residence times, good yields, and remarkably high enantioselectivity. At $60{ }^{\circ} \mathrm{C}$, with a residence time of only 2.5 minutes, the nitro amine $\mathbf{4 a}$ was continuously produced in $70 \%$ yield and $97 \%$ ee (entry 3 ). Similarly, the inflow reaction of $\mathrm{N}$-acetyl-protected nitroenamine $\mathbf{3 b}$ with Hantzsch ester $\mathbf{5}$ afforded the corresponding amine $\mathbf{4 b}$ in $70 \%$ yield and $93 \%$ ee (entry 5 ).

Under the same conditions as Table 1, entry 3, by using a $4 \mu \mathrm{L} / \mathrm{min}$ flow rate in a $10-\mu \mathrm{L}$ microreactor, the reaction was successfully extended to other 1-aryl-substituted nitroenamines, $\mathbf{3 c}-\mathbf{e}$; the reductions led to the corresponding nitroamines $\mathbf{4 c - e}$ in similar yields and with enantioselectivities consistently higher than $90 \%$ (Table 1 , entries $6-8$ ).

Then, a coil-reactor, realized by using PTFE tubing (1.58$\mathrm{mm}$ o.d., $0.58 \mathrm{~mm}$ i.d., 1.89-m length, 500- $\mu \mathrm{L}$ effective volume) coiled in a bundle and immersed in an oil bath heated to the desired temperature, was employed to realize a first scale-up of the process (Table 2 ).

At $40{ }^{\circ} \mathrm{C}$ with a 10 minute residence time, the reduction of $3 \mathbf{a}$ afforded $\mathbf{4} \mathbf{a}$ in $31 \%$ yield and $96 \%$ ee (Table 2, entry 1 ). In attempts to further improve the productivity, the flow rate was decreased and the reaction temperature increased up to $60{ }^{\circ} \mathrm{C}$ (entry 3 ): the product was then isolated in $55 \%$ yield and $97 \%$ ee.

However, it should be noted that the reaction could be efficiently performed also with $5 \mathrm{~mol} \%$ catalyst loading (Table 2 , entry 6 ) affording the product in $47 \%$ yield and $97 \%$ ee at $40{ }^{\circ} \mathrm{C}$. The reaction could be performed with comparable yield also in dichloromethane, although with a small decrease in the enantioselectivity ( $90 \%$ ee vs $97 \%$ ee in toluene).

It is interesting to attempt a comparison of the results obtained by running the reaction in batch or in flow (Table 3 ). Under the conditions of Table 2, entry 3, using a 25 $\mu \mathrm{L} / \mathrm{min}$ flow rate in a $500-\mu \mathrm{L}$ microreactor, the product $4 \mathrm{a}$ was continuously synthesized with a space time yield,

Table 1 In-Flow Organocatalytic Reduction of Nitroenamines in Microreactor ${ }^{\mathrm{a}}$

\begin{tabular}{|c|c|c|c|c|c|c|c|}
\hline Entry & $\mathrm{R}, \mathrm{Ar}$ & 3 & Flow $(\mu \mathrm{L} / \mathrm{min})$ & Residence time (min) & Temp $\left({ }^{\circ} \mathrm{C}\right)$ & Conv. ${ }^{\mathrm{b}}(\%)$ & $\mathrm{ee}^{\mathrm{c}}(\%)$ \\
\hline 1 & $\mathrm{Boc}, \mathrm{Ph}$ & $3 a$ & 2 & 5 & 40 & 50 & $>99$ \\
\hline 2 & $\mathrm{Boc}, \mathrm{Ph}$ & $3 a$ & 2 & 5 & 60 & 70 & 97 \\
\hline 3 & Boc, $\mathrm{Ph}$ & $3 a$ & 4 & 2.5 & 60 & 70 & 97 \\
\hline 4 & $\mathrm{Boc}, \mathrm{Ph}$ & $3 a$ & 4 & 2.5 & 80 & 70 & 96 \\
\hline 5 & $\mathrm{Ac}, \mathrm{Ph}$ & $3 b$ & 4 & 2.5 & 60 & 70 & 93 \\
\hline 6 & Ac, $4-\mathrm{MeOC}_{6} \mathrm{H}_{4}$ & $3 c$ & 4 & 2.5 & 60 & 40 & 92 \\
\hline 7 & Ac, $4-\mathrm{BrC}_{6} \mathrm{H}_{4}$ & $3 d$ & 4 & 2.5 & 60 & 80 & 91 \\
\hline 8 & Boc, 4- $\mathrm{MeC}_{6} \mathrm{H}_{4}$ & $3 e$ & 4 & 2.5 & 60 & 70 & 98 \\
\hline
\end{tabular}

${ }^{a}$ Reaction conditions: $0.2-0.5 \mathrm{mmol}$ scale, 5 (1.2 equiv), cat. B (10 mol\%), toluene $(0.05 \mathrm{M})$.

${ }^{\mathrm{b}}$ Conversion determined by ${ }^{5} \mathrm{H}$ NMR spectra.

c Determined by HPLC on chiral stationary phase; absolute configuration established by comparison of optical rotation values. 
Table 2 Organocatalytic Reduction of Nitroenamines in a PTFE Mesoreactor ${ }^{\mathrm{a}}$

\begin{tabular}{|c|c|c|c|c|c|c|c|}
\hline Entry & $\mathrm{R}, \mathrm{Ar}$ & 3 & Flow $(\mu \mathrm{L} / \mathrm{min})$ & Residence time (min) & Temp $\left({ }^{\circ} \mathrm{C}\right)$ & Conv. ${ }^{b}(\%)$ & $\mathrm{ee}^{\mathrm{c}}(\%)$ \\
\hline 1 & Boc, $\mathrm{Ph}$ & $3 a$ & 50 & 10 & 40 & 31 & 96 \\
\hline 2 & $\mathrm{Boc}, \mathrm{Ph}$ & $3 a$ & 25 & 20 & 40 & 45 & 96 \\
\hline 3 & Boc, $\mathrm{Ph}$ & $3 a$ & 25 & 20 & 60 & 55 & 97 \\
\hline 4 & $\mathrm{Boc}, \mathrm{Ph}$ & $3 a$ & 50 & 10 & 60 & 43 & 96 \\
\hline 5 & Boc, $\mathrm{Ph}$ & $3 a$ & 100 & 5 & 60 & 35 & 96 \\
\hline $6^{d}$ & Boc, $\mathrm{Ph}$ & $3 a$ & 50 & 10 & 40 & 47 & 97 \\
\hline 7 & $\mathrm{Ac}, \mathrm{Ph}$ & $3 \mathbf{b}$ & 50 & 10 & 60 & 57 & 93 \\
\hline 8 & $\mathrm{Ac}, \mathrm{Ph}$ & $3 b$ & 25 & 20 & 60 & 65 & 91 \\
\hline $9^{e}$ & $\mathrm{Ac}, \mathrm{Ph}$ & $3 b$ & 25 & 20 & 60 & 80 & 93 \\
\hline $10^{f}$ & $\mathrm{Ac}, \mathrm{Ph}$ & $3 b$ & 50 & 10 & 60 & 35 & 91 \\
\hline $11^{f}$ & $\mathrm{Ac}, \mathrm{Ph}$ & $3 b$ & 25 & 20 & 60 & 50 & 90 \\
\hline
\end{tabular}

a Reaction conditions: $0.2-0.5 \mathrm{mmol}$ scale, 5 (1.2 equiv), cat. B (10 mol\%), toluene $(0.05 \mathrm{M})$.

${ }^{\mathrm{b}}$ Conversion determined by ${ }^{1} \mathrm{H}$ NMR.

' Determined by HPLC on chiral stationary phase; absolute configuration established by comparison of optical rotation values.

d Reaction run with cat. B ( 5 mol\%).

e Reaction conditions: cat. B (20 mol\%), toluene (0.08 M).

${ }^{\mathrm{f}}$ Reaction was performed in dry $\mathrm{CH}_{2} \mathrm{Cl}_{2}(0.2 \mathrm{M})$.

calculated as mmol of product per volume of the reactor per reaction time, of $82 \mathrm{mmol} / \mathrm{mL}^{-1} \mathrm{~h}^{-1}$ (Table 3, entry 4). Notably, by increasing the reaction concentration (conditions of Table 2, entry 9) the space time yield doubled to 192, ten times higher than the values calculated for the batch process (19-20, see entries 6 and 7; also the space time yield of the batch reaction at $80 \%$ conversion, after 5 hours, 57 , is lower compared to the flow reaction). With microreactors, space time yields were even higher, up to $960 \mathrm{mmol} / \mathrm{mL}^{-1} \mathrm{~h}^{-1}$ (Table 3, entries 1-3).

For the sake of comparison, data from some preliminary kinetic studies are reported in Figure 1, where the yields of the reduction of nitroenamine $\mathbf{3 b}$ performed in batch or in flow under the same conditions [cat. B (10 $\mathrm{mol} \%)$, toluene $\left.(0.05 \mathrm{M}), 60^{\circ} \mathrm{C}\right]$ at different reaction times are reported.
Even after a short reaction time (less than $20 \mathrm{~min}$ ), the yields of the batch process are clearly lower compared to those observed by performing the reaction in the mesoreactor, where a $65 \%$ yield was observed after 20 minutes (Table 2 , entry 8 ), while in batch $18 \%$ yield was determined. In a microreactor, the reduction worked even better, affording the product in $70 \%$ yield after only 2.5 minutes (Table 1 , entry 5), always maintaining a very high level of enantioselectivity, consistently higher than $91 \%$.

The continuous-flow reduction of the nitro group to amine was then performed with a ThalesNano H-Cube Mini $^{\mathrm{TM}}$, equipped with a $10 \%$ Raney Ni cartridge (Scheme 4). ${ }^{12}$ After preliminary studies on chiral amine $\mathbf{4 a}$, it was found that the continuous-flow hydrogenation ${ }^{13}$ could be efficiently performed operating at $50{ }^{\circ} \mathrm{C}$ and 50 bar leading

Table 3 Comparison of Batch and Flow Catalytic Reduction of Nitroenamines

\begin{tabular}{|c|c|c|c|c|c|c|c|}
\hline Entry & Reactor & 3 & $\begin{array}{l}\text { Residence time } \\
\text { (min) }\end{array}$ & Temp. $\left({ }^{\circ} \mathrm{C}\right)$ & Conv. (\%) & ee $(\%)$ & Space-time yield \\
\hline 1 & glass $10 \mu \mathrm{L}$ & $3 a$ & 2.5 & 60 & 70 & 97 & 840.0 \\
\hline 2 & glass $10 \mu \mathrm{L}$ & $3 b$ & 2.5 & 60 & 70 & 93 & 840.0 \\
\hline 3 & glass $10 \mu \mathrm{L}$ & $3 d$ & 2.5 & 60 & 80 & 91 & 960.0 \\
\hline 4 & PTFE $0.5 \mathrm{~mL}$ & $3 a$ & 20 & 40 & 55 & 97 & 82.0 \\
\hline 5 & PTFE $0.5 \mathrm{~mL}$ & $3 b$ & 20 & 60 & 80 & 93 & 192.0 \\
\hline $6^{b}$ & batch & $3 a$ & & 60 & 90 & 99 & 19.3 \\
\hline $7^{b}$ & batch & $3 b$ & & 60 & 97 & 99 & 20.8 \\
\hline
\end{tabular}

a Calculated as mmol product/reactor volume $\times$ reaction time $\times 1000\left(\mathrm{mmol} / \mathrm{mL}^{-1} \mathrm{~h}^{-1}\right)$.

b Reaction conditions: 5 (1.2 equiv), cat. B ( 5 mol\%), toluene $(0.3 \mathrm{M}), 14 \mathrm{~h}$. 


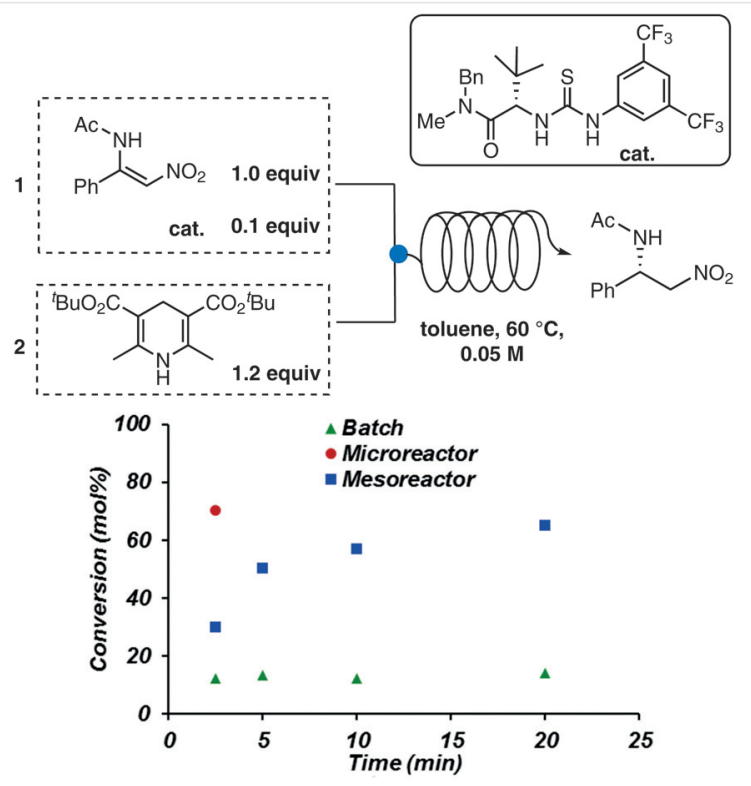

Figure 1 Comparison of in-batch and in-flow (micro- and mesoreactors) reduction of $\mathbf{3 b}$. Reaction conditions: cat. B (10 mol\%), 5 (1.2 equiv), toluene $(0.05 \mathrm{M}), 60^{\circ} \mathrm{C}$.

to the isolation of the diamine derivative $\mathbf{6 a}$ in $75 \%$ yield after 5 hours. Analogously, the reduction of $\mathrm{N}$-acetyl derivative $\mathbf{4 b}$ afforded the product $\mathbf{6 b}$ in $92 \%$ yield, without any loss of stereochemical integrity (see the Supporting Information).

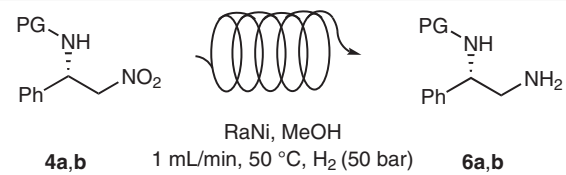

Scheme 4 Raney Ni catalyzed continuous-flow hydrogenation of the nitro group

In an attempt to develop a completely metal-free twostep, continuous-flow process for the stereoselective, catalytic synthesis of 1,2-diamines, the reduction of the nitro group was also performed by employing trichlorosilane as a very convenient, atoxic and inexpensive reducing agent, in the presence of a tertiary amine (Scheme 5). ${ }^{14,15}$ It was observed that the continuous-flow reduction of $\mathrm{N}$-acetyl amino nitro derivative $\mathbf{4 b}$ could be realized in a PTFE mesoreactor in dichloromethane as the reaction solvent; the expected $N$-acetyl-monoprotected 1,2-diamine $\mathbf{6 b}$ was produced in $60 \%$ yield and with the same optical purity of the starting material (for further details, see the Supporting Information).

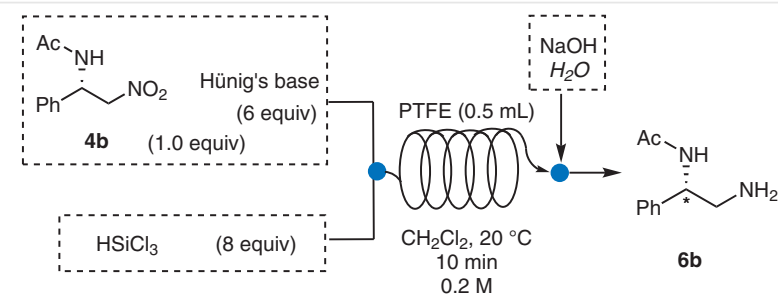

Scheme 5 Metal-free continuous-flow reduction of the nitro group

Finally, a multistep, in continuo synthesis of chiral mono$\mathrm{N}$-acetyl-protected diamine $\mathbf{6 b}$ was studied (Scheme 6).

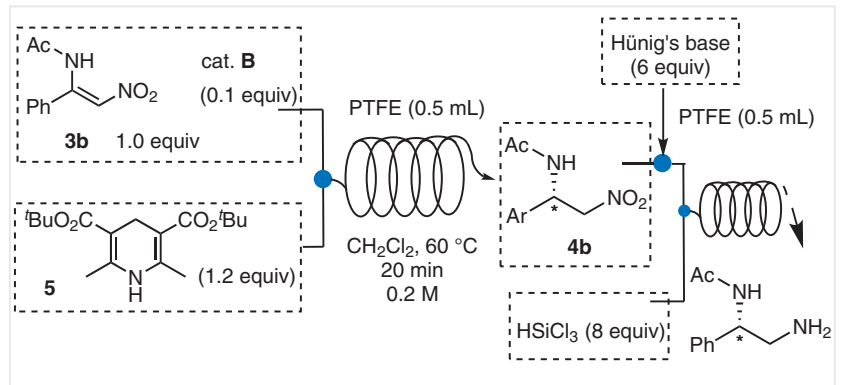

$6 b$

Scheme 6 Multistep in-flow synthesis of chiral 1,2-diamino derivatives

After the first enantioselective, organocatalytic step in dichloromethane, the organic solution was directly introduced into a second reactor for the nitro group reduction. However, the presence of considerable amounts of unreacted nitroenamine led to the formation of several byproducts and, at the end, only traces of the final product were detected.

Therefore, we decided to study a different procedure, reported in Scheme 7. After performing the catalytic enantioselective reduction under the standard conditions in toluene, in a PTFE mesoreactor, the product $\mathbf{4 b}$ was further reacted in a flask, where the nitro reduction was accomplished by adding the combination of reducing reagents $\left(\mathrm{HSiCl}_{3} / \mathrm{DIPEA}\right)$ which were mixed in situ in a second PTFE mesoreactor. The mono- $N$-acetyl-protected diamine 6b was detected ( $30 \%$ yield) and converted into the diacetyl product 7, which was purified (27\% isolated yield) and completely characterized.

In conclusion, the enantioselective, metal-free catalytic reduction of nitroenamines was accomplished for the first time under continuous-flow conditions. Microreactors were used in a preliminary screening that allowed the bestperforming conditions to be established, that were successfully replicated in a mesoreactor, obtaining remarkably high productivities and enantioselectivities consistently higher than $90 \%$. The nitro group reduction was also successfully realized, either by continuous-flow nickel-catalyzed hydrogenation or by continuous-flow trichlorosilane-mediated reduction. The present work is a further demonstration that 


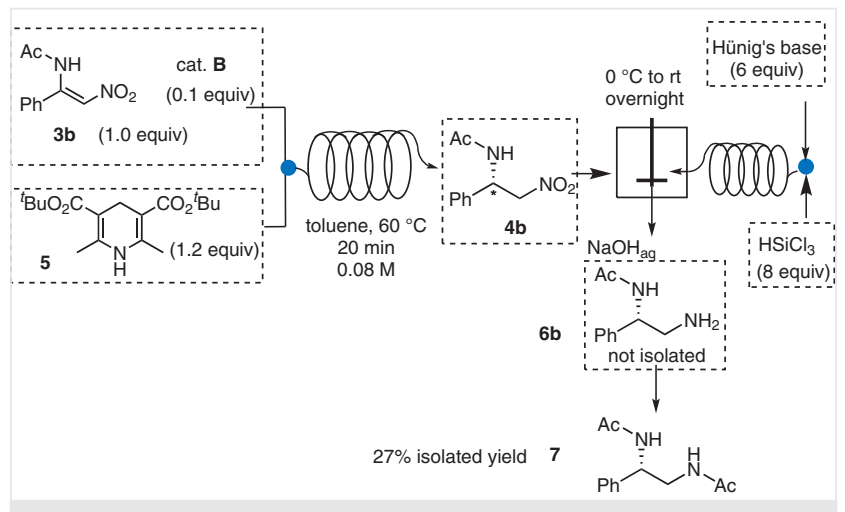

Scheme 7 Multistep in-flow synthesis of chiral 1,2-diamino derivatives

the development of a multistep continuous-flow process for the synthesis of enantiomerically pure products is today feasible and will bring to further applications in the near future.

Commercial grade reagents and solvents were used without further purifications. ${ }^{1} \mathrm{H}$ NMR and ${ }^{13} \mathrm{C}$ NMR spectra were recorded with instruments at $300 \mathrm{MHz}$ (Bruker F300) with the solvent as reference. MS were registered on an APEX II \& Xmass software (Bruker Daltonics) instrument or on a thermo Finnigan LCQ Advantage instrument, equipped with an ESI ion source. Optical rotations were obtained on a Perkin-Elmer 241 polarimeter at $589 \mathrm{~nm}$ using a 5-mL cell, with a length of $1 \mathrm{dm}$. For HPLC analyses on chiral stationary phase, an Agilent Instrument Series 1100 was used to determine ee; the specific operative conditions for each product are reported. Reactions and chromatographic purifications were monitored by analytical TLC using silica gel 60 F254 pre-coated glass plates and visualized using UV light, phosphomolybdic acid, or ninhydrin. Purification of the products was performed by flash column chromatography (according to the Still method) using as stationary phase silica gel 230-400 mesh (Sigma Aldrich). $\mathrm{CH}_{2} \mathrm{Cl}_{2}$ was dried by distillation under an $\mathrm{N}_{2}$ atmosphere on $\mathrm{CaH}_{2}$. Other dry solvents used are commercially available and they are stored under $\mathrm{N}_{2}$ over molecular sieves (bottles with crown cap). Commercially available $\mathrm{HSiCl}_{3}$ was freshly distilled before use. The fluidic device was realized by assembling one coil-reactor according to the scheme reported in the Supporting Information. The coil reactor was realized by using PTFE tubing (1.58-mm o.d., 0.58$\mathrm{mm}$ i.d., $1.89-\mathrm{m}$ length, $500-\mu \mathrm{L}$ effective volume) coiled in a bundle and immersed in an oil bath heated to the desired temperature. Chemix Fusion 100, equipped with two 2.5-mL Hamilton gastight syringes, fed the solution containing the nitroenamine and the catalyst dissolved in toluene, and the solution of Hantzsch ester in toluene through a T-junction into the coil-reactor.

\section{B-Amino- $\alpha$-nitrostyrene; General Procedure}

$\mathrm{Et}_{3} \mathrm{~N}(0.7 \mathrm{~mL}, 5.0 \mathrm{mmol})$ was added to a solution of $\mathrm{MeONH}_{2} \cdot \mathrm{HCl}(0.42$ $\mathrm{g}, 5.0 \mathrm{mmol})$ in DMF $(8 \mathrm{~mL})$ at $0{ }^{\circ} \mathrm{C}$. $\beta$-Nitrostyrene $(0.745 \mathrm{~g}, 5.0$ $\mathrm{mmol}$ ) was then added and the resulting suspension was stirred at 0 ${ }^{\circ} \mathrm{C}$ for $15 \mathrm{~min}$ and at $\mathrm{rt}$ for $5 \mathrm{~min}$. The precipitate was removed by filtration and washed with a small amount of DMF. The combined filtrate was transferred into an addition funnel and was added dropwise to a KOt-Bu $(1.12 \mathrm{~g}, 10 \mathrm{mmol})$ solution in DMF $(12 \mathrm{~mL})$ at $0{ }^{\circ} \mathrm{C}$. The cooling bath was then removed and the mixture was stirred for 30 min at rt. The reaction was quenched with sat. aq $\mathrm{NH}_{4} \mathrm{Cl}(30 \mathrm{~mL})$. The solvents were distilled in vacuo and the residue was dissolved in $\mathrm{CH}_{2} \mathrm{Cl}_{2}$. The obtained organic phase was washed with water and brine, dried $\left(\mathrm{Na}_{2} \mathrm{SO}_{4}\right)$, filtered and concentrated in vacuo. The crude $\beta$ amino- $\alpha$-nitrostyrene was used without further purification in the next step.

\section{tert-Butyl (Z)-2-Nitro-1-phenylvinylcarbamate (3a); Typical Pro- cedure $A$ (TPA)}

A stirred solution of crude $\beta$-amino- $\alpha$-nitrostyrene in $\mathrm{CH}_{2} \mathrm{Cl}_{2}(8.3 \mathrm{~mL}$, $0.6 \mathrm{M})$ was cooled to $0{ }^{\circ} \mathrm{C}$. To this was added $\mathrm{Boc}_{2} \mathrm{O}(1.3 \mathrm{~g}, 6 \mathrm{mmol})$ followed by DMAP $(0.03 \mathrm{~g}, 0.25 \mathrm{mmol})$ and the cooling bath was then removed and the solution was stirred at $\mathrm{rt}$ for $1 \mathrm{~h}$. The reaction was then quenched with water and extracted with $\mathrm{CH}_{2} \mathrm{Cl}_{2}$. The combined organic phases were dried $\left(\mathrm{Na}_{2} \mathrm{SO}_{4}\right)$, filtered, concentrated in vacuo, and the residue was purified by flash column chromatography (silica gel, $\mathrm{CH}_{2} \mathrm{Cl}_{2}$ /petroleum ether $3: 1, R_{f}=0.21$ ) to give nitroenamine 3a $(0.8 \mathrm{~g}, 60 \%)$ as a pale yellow solid with spectroscopic data in agreement with the literature. ${ }^{4}$

${ }^{1} \mathrm{H}$ NMR (300 MHz, $\left.\mathrm{CDCl}_{3}\right): \delta=10.31(\mathrm{~s}, 1 \mathrm{H}, \mathrm{NH}), 7.54-7.44(\mathrm{~m}, 5 \mathrm{H}$, $\left.\mathrm{C}_{6} \mathrm{H}_{5}\right), 6.66\left(\mathrm{~s}, 1 \mathrm{H}, \mathrm{CHNO}_{2}\right), 1.41\left(\mathrm{~s}, 9 \mathrm{H}, 3 \mathrm{CH}_{3}\right)$.

\section{(Z)-N-(2-Nitro-1-phenylvinyl)acetamide (3b); Typical Procedure B (TPB)}

A stirred solution of crude $\beta$-amino- $\alpha$-nitrostyrene in toluene (16.5 $\mathrm{mL}$ ) was cooled to $0{ }^{\circ} \mathrm{C}$ and to this was added $\mathrm{Et}_{3} \mathrm{~N}(2.7 \mathrm{~mL}, 20 \mathrm{mmol})$ followed by $\mathrm{Ac}_{2} \mathrm{O}$ ( $\left.1.4 \mathrm{~mL}, 15 \mathrm{mmol}\right)$. The cooling bath was then removed and the solution was stirred at $45{ }^{\circ} \mathrm{C}$ overnight. The mixture was concentrated under vacuum and the residue was purified by flash column chromatography (silica gel, $\mathrm{CH}_{2} \mathrm{Cl}_{2} /$ EtOAc 9:1, $R_{f}=0.68$ ) to give nitroenamine $\mathbf{3 b}(0.515 \mathrm{~g}, 50 \%)$ as a pale yellow solid with spectroscopic data in agreement with the literature. ${ }^{4}$

${ }^{1} \mathrm{H}$ NMR (300 MHz, $\left.\mathrm{CDCl}_{3}\right): \delta=10.82(\mathrm{~s}, 1 \mathrm{H}, \mathrm{NH}), 7.54-7.38(\mathrm{~m}, 5 \mathrm{H}$, $\left.\mathrm{C}_{6} \mathrm{H}_{5}\right), 6.72\left(\mathrm{~s}, 1 \mathrm{H}, \mathrm{CHNO}_{2}\right), 2.27\left(\mathrm{~s}, 3 \mathrm{H}, \mathrm{CH}_{3}\right)$.

\section{(Z)-N-[1-(4-Methoxyphenyl)-2-nitrovinyl]acetamide (3c)}

$\alpha$-Amino-4-methoxy- $\beta$-nitrostyrene, synthesized from 4-methoxy- $\beta$ nitrostyrene $(0.64 \mathrm{~g}, 3.6 \mathrm{mmol})$ by the general procedure, was subjected to TPB. Purification of the crude by column chromatography $\left(\mathrm{CH}_{2} \mathrm{Cl}_{2} /\right.$ EtOAc $\left.95: 5, R_{f}=0.67\right)$ gave nitroenamine $3 \mathrm{c}(0.3 \mathrm{~g}, 35 \%)$ as a white solid with spectroscopic data in agreement with the literature. ${ }^{4}$ ${ }^{1} \mathrm{H}$ NMR $\left(300 \mathrm{MHz}, \mathrm{CDCl}_{3}\right): \delta=10.80(\mathrm{~s}, 1 \mathrm{H}, \mathrm{NH}), 7.38-7.36(\mathrm{~m}, 2 \mathrm{H}$, $\mathrm{Ar}), 6.96-6.93(\mathrm{~m}, 2 \mathrm{H}, \mathrm{Ar}), 6.74\left(\mathrm{~s}, 1 \mathrm{H}, \mathrm{CHNO}_{2}\right), 3.86\left(\mathrm{~s}, 3 \mathrm{H}, \mathrm{OCH}_{3}\right)$, $2.24\left(\mathrm{~s}, 3 \mathrm{H}, \mathrm{COCH}_{3}\right)$.

\section{(Z)-N-[1-(4-Bromophenyl)-2-nitrovinyl]acetamide (3d)}

$\alpha$-Amino-4-bromo- $\beta$-nitrostyrene, synthesized from 4 -bromo- $\beta$-nitrostyrene $(1.14 \mathrm{~g}, 5 \mathrm{mmol})$ by the general procedure, was subjected to TPB. Purification of the crude by column chromatography $\left(\mathrm{CH}_{2}-\right.$ $\mathrm{Cl}_{2} /$ EtOAc 9:1, $\left.R_{f}=0.78\right)$ gave nitroenamine $3 \mathbf{d}(0.42 \mathrm{~g}, 30 \%)$ as a pale brown solid with spectroscopic data in agreement with the literature. $^{16}$

${ }^{1} \mathrm{H}$ NMR $\left(300 \mathrm{MHz}, \mathrm{CDCl}_{3}\right): \delta=10.81(\mathrm{~s}, 1 \mathrm{H}, \mathrm{NH}), 7.60-7.57(\mathrm{~m}, 2 \mathrm{H}$, Ar), 7.28-7.26 (m, $2 \mathrm{H}, \mathrm{Ar}), 6.68\left(\mathrm{~s}, 1 \mathrm{H}, \mathrm{CHNO}_{2}\right), 2.28\left(\mathrm{~s}, 3 \mathrm{H}, \mathrm{COCH}_{3}\right)$.

\section{tert-Butyl (Z)-[2-Nitro-1-(p-tolyl)vinyl]carbamate (3e)}

$\alpha$-Amino-4-methyl- $\beta$-nitrostyrene, synthesized from 4-methyl- $\beta$ nitrostyrene $(0.815 \mathrm{~g}, 5 \mathrm{mmol})$ by the general procedure, was subjected to TPA. Purification of the crude by column chromatography 
$\left(\mathrm{CH}_{2} \mathrm{Cl}_{2} /\right.$ petroleum ether $\left.3: 1, R_{f}=0.46\right)$ gave nitroenamine $3 \mathbf{e}(0.695 \mathrm{~g}$, $50 \%$ as a pale yellow solid with spectroscopic data in agreement with the literature. ${ }^{4}$

${ }^{1} \mathrm{H}$ NMR $\left(300 \mathrm{MHz}, \mathrm{CDCl}_{3}\right): \delta=10.30(\mathrm{~s}, 1 \mathrm{H}, \mathrm{NH}), 7.33-7.31(\mathrm{~m}, 2 \mathrm{H}$, $\mathrm{Ar}), 7.28-7.24(\mathrm{~m}, 2 \mathrm{H}, \mathrm{Ar}), 6.66\left(\mathrm{~s}, 1 \mathrm{H}, \mathrm{CHNO}_{2}\right), 2.43\left(\mathrm{~s}, 3 \mathrm{H}, \mathrm{CH}_{3}\right)$, $1.43\left(\mathrm{~s}, 9 \mathrm{H}, \mathrm{CCH}_{3}\right)$.

\section{Reduction of $\beta$-Nitroenamines with Hantzsch Ester under Contin-} uous Flow; General Procedure

The reactor ( $500 \mu \mathrm{L}$ coil-reactor or $10 \mu \mathrm{L}$ microreactor) heated at the desired temperature was fed with two 2.5 -mL Hamilton gastight syringes, at the selected flow rate. In the case of reactions run in $\mathrm{CH}_{2} \mathrm{Cl}_{2}$, the coil reactor was equipped with a back pressure regulator $(100 \mathrm{psi}$, 6.9 bar) in order to be able to heat at $60^{\circ} \mathrm{C}$. Syringe A was filled with a $0.1 \mathrm{M}$ solution of $\beta$-nitroenamine $(0.25 \mathrm{mmol}, 1$ equiv $)$ and catalyst $\mathbf{B}$ ( $0.025 \mathrm{mmol}, 0.1$ equiv) in dry toluene $(2.5 \mathrm{~mL})$. Syringe B was filled with a solution of Hantzsch ester $\mathbf{5}(0.3 \mathrm{mmol}, 1.2$ equiv) dissolved in dry toluene. The mixture was collected into vials cooled to $0{ }^{\circ} \mathrm{C}$. The solvent was then removed under high vacuum, and the crude mixture subjected to ${ }^{1} \mathrm{H}$ NMR. After the first two volumes were discharged, the steady-state conditions were reached; the reported yield values are given as average of five different samples collected at different times.

\section{tert-Butyl (S)-(2-Nitro-1-phenylethyl)carbamate (4a)}

Prepared according to the general procedure. The crude mixture was purified by column chromatography (silica gel, $\mathrm{CH}_{2} \mathrm{Cl}_{2}$ /hexane $6: 1$, $R_{f}=0.3$ ) to afford $4 \mathrm{a}$ as a white solid. All analytical data are in agreement with the literature. ${ }^{4}$ The enantiomeric excess was determined by HPLC [chiral stationary phase, Daicel Chiralcel OJ-H column, eluent hexane $/ i$-PrOH 9:1, flow rate $0.75 \mathrm{~mL} / \mathrm{min}, \lambda=210 \mathrm{~nm}): t_{\mathrm{R}}=21(\mathrm{mi}-$ nor), 23 min (major).

${ }^{1} \mathrm{H}$ NMR (300 MHz, $\left.\mathrm{CDCl}_{3}\right): \delta=7.39-7.32(\mathrm{~m}, 5 \mathrm{H}, \mathrm{Ph}), 5.40(\mathrm{~m}, 2 \mathrm{H}$, CHNHAc), $4.84\left(\mathrm{~m}, 1 \mathrm{H}, \mathrm{CH}_{2} \mathrm{NO}_{2}\right.$ ), 4.71 (dd, $\left.1 \mathrm{H}, \mathrm{CH}_{2} \mathrm{NO}_{2}\right), 1.47$ (s, $9 \mathrm{H}$, $\left.\mathrm{CCH}_{3}\right)$.

\section{(S)-N-(2-Nitro-1-phenylethyl)acetamide (4b)}

Prepared according to the general procedure. The crude mixture was purified by column chromatography (hexane/EtOAc $1: 4, R_{f}=0.4$ ) to afford $\mathbf{4 b}$ as a white solid. All analytical data are in agreement with the literature. ${ }^{4}$ The enantiomeric excess was determined by HPLC (chiral stationary phase, Daicel Chiralcel OJ-H column, eluent hexane $/ i$-PrOH 9:1, flow rate $0.75 \mathrm{~mL} / \mathrm{min}, \lambda=210 \mathrm{~nm}$ ): $t_{\mathrm{R}}=52.8$ (minor), 45.7 min (major).

${ }^{1} \mathrm{H} \mathrm{NMR}\left(300 \mathrm{MHz}, \mathrm{CDCl}_{3}\right): \delta=7.42-7.32(\mathrm{~m}, 5 \mathrm{H}, \mathrm{Ph}), 6.25$ (br s, $1 \mathrm{H}$, $\mathrm{NH}), 5.70$ (q, $1 \mathrm{H}, \mathrm{CHNHAc}), 4.95$ (dd, $1 \mathrm{H}, \mathrm{CH}_{2} \mathrm{NO}_{2}$ ), 4.77 (dd, $1 \mathrm{H}$, $\left.\mathrm{CH}_{2} \mathrm{NO}_{2}\right), 2.09$ (s, $3 \mathrm{H}, \mathrm{CH}_{2} \mathrm{NO}_{2}$ ).

\section{(S)-N-[1-(4-Methoxyphenyl)-2-nitroethyl]acetamide (4c)}

Prepared according to the general procedure. The crude mixture was purified by column chromatography (silica gel, hexane/EtOAc $1: 4, R_{f}=$ 0.7 ) to afford $\mathbf{4 c}$ as a white solid. All analytical data are in agreement with the literature. ${ }^{4}$ The enantiomeric excess was determined by HPLC (chiral stationary phase, Phenomenex Lux-Cellulose- 3 column, eluent hexane/i-PrOH 9:1, flow rate $0.75 \mathrm{~mL} / \mathrm{min}, \lambda=210 \mathrm{~nm}$ ): $t_{\mathrm{R}}=18$ (minor), 15 min (major).

${ }^{1} \mathrm{H} \mathrm{NMR}\left(300 \mathrm{MHz}, \mathrm{CDCl}_{3}\right.$ ): $\delta=7.25$ (d, $2 \mathrm{H}, \mathrm{Ar}$ ), 6.93 (d, $2 \mathrm{H}, \mathrm{Ar}$ ), 6.12 (d, $1 \mathrm{H}, \mathrm{NH}), 5.62(\mathrm{~m}, 1 \mathrm{H}, \mathrm{CHNHAc}), 4.93$ (dd, $1 \mathrm{H}, \mathrm{CH}_{2} \mathrm{NO}_{2}$ ), 4.72 (dd, $\left.1 \mathrm{H}, \mathrm{CH}_{2} \mathrm{NO}_{2}\right), 3.82\left(\mathrm{~s}, 3 \mathrm{H}, \mathrm{OCH}_{3}\right), 2.07\left(\mathrm{~s}, 3 \mathrm{H}, \mathrm{COCH}_{3}\right)$.

\section{(S)-N-[1-(4-Bromophenyl)-2-nitroethyl]acetamide (4d)}

Prepared according to the general procedure. The crude mixture was purified by column chromatography (silica gel, hexane/EtOAc $1: 4, R_{f}=$ 0.4 ) to afford $4 \mathbf{d}$ as a white solid. All analytical data are in agreement with the literature. ${ }^{16}$ The enantiomeric excess was determined by HPLC (chiral stationary phase, Daicel Chiralcel AD column, eluent hexane/i-PrOH 9:1, flow rate $1 \mathrm{~mL} / \mathrm{min}, \lambda=250 \mathrm{~nm}$ ): $t_{\mathrm{R}}=26$ (minor), 15 $\min$ (major).

${ }^{1} \mathrm{H}$ NMR (300 MHz, $\mathrm{CDCl}_{3}$ ): $\delta$ = 7.52-7.51 (d, $\left.2 \mathrm{H}, \mathrm{Ar}\right), 7.22-7.19$ (d, 2 $\mathrm{H}, \mathrm{Ar}), 6.63(\mathrm{~d}, 1 \mathrm{H}, \mathrm{NH}), 5.65(\mathrm{~m}, 1 \mathrm{H}, \mathrm{CHNHAc}), 4.89\left(\mathrm{dd}, 1 \mathrm{H}, \mathrm{CH}_{2^{-}}\right.$ $\mathrm{NO}_{2}$ ), $4.72\left(\mathrm{dd}, 1 \mathrm{H}, \mathrm{CH}_{2} \mathrm{NO}_{2}\right), 2.06\left(\mathrm{~s}, 3 \mathrm{H}, \mathrm{COCH}_{3}\right)$.

\section{tert-Butyl (S)-[2-Nitro-1-(p-tolyl)ethyl]carbamate (4e)}

Prepared according to the general procedure. The crude mixture was purified by column chromatography (silica gel, $\mathrm{CH}_{2} \mathrm{Cl}_{2} /$ hexane $6: 1$, $R_{f}=0.4$ ) to afford $4 \mathbf{e}$ as a white solid. All analytical data are in agreement with the literature. ${ }^{4}$ The enantiomeric excess was determined by HPLC (chiral stationary phase, Daicel Chiralcel OJ-H column: eluent hexane $/ i-\mathrm{PrOH} 9: 1$, flow rate $0.75 \mathrm{~mL} / \mathrm{min}, \lambda=210 \mathrm{~nm}): t_{\mathrm{R}}=20(\mathrm{mi}-$ nor), $15 \mathrm{~min}$ (major).

${ }^{1} \mathrm{H}$ NMR $\left(300 \mathrm{MHz}, \mathrm{CDCl}_{3}\right): \delta=7.20(\mathrm{~m}, 4 \mathrm{H}, \mathrm{Ar}), 5.32(\mathrm{~m}, 1 \mathrm{H}$, CHNHAc), 5.21 (br s, $1 \mathrm{H}, \mathrm{NH}$ ), $4.84\left(\mathrm{~m}, 1 \mathrm{H}, \mathrm{CH}_{2} \mathrm{NO}_{2}\right.$ ), 4.69 (dd, $1 \mathrm{H}$, $\left.\mathrm{CH}_{2} \mathrm{NO}_{2}\right), 2.36\left(\mathrm{~s}, 3 \mathrm{H}, \mathrm{CH}_{3}\right), 1.45\left(\mathrm{~s}, 9 \mathrm{H}, \mathrm{CCH}_{3}\right)$.

\section{tert-Butyl ( $S$ )-(2-Amino-1-phenylethyl)carbamate (6a)}

A $0.02 \mathrm{M}$ solution of the amine $4 \mathrm{a}(0.106 \mathrm{~g}, 0.4 \mathrm{mmol})$ dissolved in $\mathrm{MeOH}(18 \mathrm{~mL})$ was charged into a vial connected with the pump of the H-CUBE Mini, equipped with a 30-mm cartridge of Raney nickel. The instrument was previously stabilized at $50{ }^{\circ} \mathrm{C}$ and 50 bar $\mathrm{H}_{2}$ and at $1 \mathrm{~mL} / \mathrm{min}$ as flow rate. The reaction was run in a closed loop for $5 \mathrm{~h}$. After this time, the solvent was removed in vacuo, and the crude mixture dissolved in EtOAc and washed with $5 \% \mathrm{NaOH}$. The crude mixture was purified by column chromatography (silica gel, hexane/EtOAc 2:8 + $\left.1 \% \mathrm{Et}_{3} \mathrm{~N}, R_{f}=0.1\right)$ to afford $\mathbf{6 a}(0.07 \mathrm{~g}, 75 \%)$ as a yellowish liquid. All analytical data are in agreement with the literature. ${ }^{17}$

${ }^{1} \mathrm{H}$ NMR $\left(300 \mathrm{MHz}, \mathrm{CDCl}_{3}\right): \delta=7.36-7.24(\mathrm{~m}, 5 \mathrm{H}, \mathrm{Ph}$ ), 5.43 (br s, $1 \mathrm{H}$, CHNHAc), 4.66 (br s, $1 \mathrm{H}, \mathrm{CHNHAc}), 3.00\left(\mathrm{~d}, 2 \mathrm{H}, \mathrm{CH}_{2} \mathrm{NH}_{2}\right), 1.42(\mathrm{~s}, 9 \mathrm{H}$, $\left.\mathrm{CCH}_{3}\right)$.

\section{(S)-N-(2-Amino-1-phenylethyl)acetamide (6b)}

Syringe A was loaded with a solution of (S)-N-(2-nitro-1-phenylethyl)acetamide (4b) $(0.125 \mathrm{~g}, 0.6 \mathrm{mmol})$ and DIPEA (0.625 mL, 3.6 $\mathrm{mmol})$ in dry $\mathrm{CH}_{2} \mathrm{Cl}_{2}(2.5 \mathrm{~mL})$. Syringe $B$ was filled with a solution of $\mathrm{HSiCl}_{3}\left(0.480 \mathrm{~mL}, 4.8 \mathrm{mmol}, 8\right.$ equivalents) in dry $\mathrm{CH}_{2} \mathrm{Cl}_{2}(2.5 \mathrm{~mL})$. Syringes $\mathrm{A}$ and $\mathrm{B}$ were connected to a syringe pump and the reagents were pumped into the mesoreactor $(0.5 \mathrm{~mL})$ at $0.05 \mathrm{~mL} / \mathrm{min}$ at $20^{\circ} \mathrm{C}$. The outcome of the reactor was collected into vials containing $4 \mathrm{M}$ $\mathrm{NaOH}$ solution at $0{ }^{\circ} \mathrm{C}$. Five reactor volumes were collected, dried $\left(\mathrm{Na}_{2} \mathrm{SO}_{4}\right)$ and concentrated in vacuo. The product was obtained with complete conversion without further purification as a yellow solid; yield $0.06 \mathrm{~g}(60 \%)$.

$[\alpha]_{\mathrm{D}}{ }^{25}+24\left(c 0.006, \mathrm{CHCl}_{3}\right)$.

${ }^{1} \mathrm{H}$ NMR $\left(300 \mathrm{MHz}, \mathrm{CDCl}_{3}\right): \delta=7.52-7.29(\mathrm{~m}, 5 \mathrm{H}, \mathrm{Ph}), 6.44(\mathrm{br} \mathrm{s}, 1 \mathrm{H}$, CHNHAc), 5.04 (q, $1 \mathrm{H}, \mathrm{CHNHAc}$ ), 3.10 (ddd, $2 \mathrm{H}, \mathrm{CH}_{2} \mathrm{NH}_{2}$ ), 2.07 (s, $3 \mathrm{H}$, $\left.\mathrm{COCH}_{3}\right)$.

${ }^{13} \mathrm{C} \mathrm{NMR}\left(75 \mathrm{MHz}, \mathrm{CDCl}_{3}\right): \delta=169.2,143.1,128.7$ (2 C), 127.5, $126.5(2$ C), 54.6, 46.6, 126.3, 29.6.

HRMS (ESI): $m / z[M+1]$ calcd for $\mathrm{C}_{10} \mathrm{H}_{15} \mathrm{ON}_{2}$ : 179.1179; found: 179.1179. 


\section{(S)- $N, N^{\prime}$-Diacetyl-1-phenylethane-1,2-diamine (7) by Two-Step Synthesis}

Syringe A was filled with nitroenamine $\mathbf{3 b}(0.33 \mathrm{M}$ soln, $1 \mathrm{~mL})$ catalyst B (0.2 equiv); syringe B was filled with 5 ( $0.1 \mathrm{M}$ soln, $4 \mathrm{~mL})$; syringe $C$ was filled with DIPEA (6 equiv) in $\mathrm{CH}_{2} \mathrm{Cl}_{2}$ (2.5 mL, total volume); syringe D was filled with $\mathrm{HSiCl}_{3}$ (8 equiv) in $\mathrm{CH}_{2} \mathrm{Cl}_{2}(2.5 \mathrm{~mL}$, total volume). Syringes $A$ and $B$ were pumped into a $500-\mu \mathrm{L}$ mesoreactor heated to $60{ }^{\circ} \mathrm{C}$, at two different flow rates, in order to have a residence time of $20 \mathrm{~min}$ (overall rate: $25 \mu \mathrm{L} / \mathrm{min}, 5 \mu \mathrm{L} / \mathrm{min}$ for syringe A, 20 $\mu \mathrm{L} / \mathrm{min}$ for syringe $\mathrm{B}$ ), and a concentration of $0.08 \mathrm{M}$ of $\mathbf{3 b}$ in the reactor. Syringes $C$ and $D$ were pumped at the same flow rate into a 100$\mu \mathrm{L}$ mesoreactor cooled to $0{ }^{\circ} \mathrm{C}$, in order to premix the reducing agent and the Lewis base.

The outcome of the reactors was collected in the same round-bottomed flask under $\mathrm{N}_{2}$ atmosphere cooled to $0{ }^{\circ} \mathrm{C}$, where the nitro reduction took place, after the first two volumes were discharged. After stirring at rt overnight, the reaction was quenched with stoichiometric $4 \mathrm{M} \mathrm{NaOH}$ soln, dried $\left(\mathrm{Na}_{2} \mathrm{SO}_{4}\right)$, filtered, and evaporated under reduced pressure. The crude was directly subjected to derivatization.

A stirred solution of the crude in toluene $(4 \mathrm{~mL})$ was cooled to $0{ }^{\circ} \mathrm{C}$, and to this was added $\mathrm{Et}_{3} \mathrm{~N}$ (4.0 equiv) followed by $\mathrm{Ac}_{2} \mathrm{O}$ (3.0 equiv). The cooling bath was then removed and the solution was stirred at $45^{\circ} \mathrm{C}$ overnight. The mixture was then concentrated under vacuum and the residue was purified by flash column chromatography (silica gel, $\mathrm{CH}_{2} \mathrm{Cl}_{2} / \mathrm{MeOH}$ 9:1) to afford 7 (16 mg, 27\%) as a yellow solid. All analytical data are in agreement with the literature. ${ }^{18}$ The enantiomeric excess was determined by HPLC (chiral stationary phase, Daicel Chiralcel OJ-H column, eluent hexane/i-PrOH 9:1, flow rate 0.8 $\mathrm{mL} / \mathrm{min}, \lambda=210 \mathrm{~nm}$ ): $t_{\mathrm{R}}=9$ (minor), $10.4 \mathrm{~min}$ (major). In all the cases the enantiomeric excess was maintained during the reduction of the nitro group.

${ }^{1} \mathrm{H}$ NMR (300 MHz, CD ${ }_{3} \mathrm{OD}$ ): $\delta=7.36-7.20(\mathrm{~m}, 5 \mathrm{H}, \mathrm{Ph}), 5.07(\mathrm{~m}, 1 \mathrm{H}$, CHNHAc), 3.49 (m, $\left.2 \mathrm{H}, \mathrm{CH}_{2} \mathrm{NHAc}\right), 2.00\left(\mathrm{~s}, 3 \mathrm{H}, \mathrm{COCH}_{3}\right), 1.92(\mathrm{~s}, 3 \mathrm{H}$, $\left.\mathrm{COCH}_{3}\right)$.

\section{Funding Information}

M.P. acknowledges Università degli Studi di Milano for a pre-doctoral fellowship. M.B. thanks Università degli Studi di Milano for a H2020Transition Grant. M.E.C. thanks Fondazione Cariplo for a postdoctoral grant.

\section{Supporting Information}

Supporting information for this article is available online at https://doi.org/10.1055/s-0036-1591911.

\section{References}

(1) Chiral Amine Synthesis: Methods, Developments and Applications; Nugent, T. C., Ed.; Wiley-VCH: Weinheim, 2010.

(2) Reviews: (a) Lucet, D.; LeGall, T.; Mioskowski, C. Angew. Chem. Int. Ed. 1998, 37, 2580. (b) Ballini, R.; Petrini, M. Tetrahedron 2004, 60, 1017. (c) Kotti, S. R.; Timmons, C.; Li, G. Chem. Biol. Drug Des. 2006, 67, 101.

(3) Liu, X. W.; Yan, Y.; Wang, Y.-Q.; Wang, C.; Sun, J. Chem. Eur. J. 2012, 18, 9204.
(4) Ferraro, A.; Bernardi, L.; Fochi, M. Adv. Synth. Catal. 2016, 358, 1561.

(5) For reviews on organocatalyzed enantioselective reductions see: (a) Benaglia, M.; Genoni, A.; Bonsignore, M. Enantioselective Organocatalytic Reductions, In Stereoselective Organocatalysis: Bond Formation Methodologies and Activation Modes; Rios Torres, R., Ed.; Wiley: Hoboken, 2013, 559-585. (b) Rossi, S.; Benaglia, M.; Massolo, E.; Raimondi, L. Catal. Sci. Technol. 2014, 9, 2708.

(6) Massolo, E.; Benaglia, M.; Orlandi, M.; Rossi, S.; Celentano, G. Chem. Eur. J. 2015, 21, 3589.

(7) (a) Genoni, A.; Benaglia, M.; Massolo, E.; Rossi, S. Chem. Commun. 2013, 49, 8365. For reviews see: (b) Guizzetti, S.; Benaglia, M. Eur. J. Org. Chem. 2010, 5529. (c) Jones, S.; Warner, C. J. A. Org. Biomol. Chem. 2012, 10, 2189.

(8) Recent reviews: (a) Atodiresei, I.; Vila, C.; Rueping, M. ACS Catal. 2015, 5, 1972. (b) Puglisi, A.; Benaglia, M.; Porta, R.; Coccia, F. Curr. Organocatal. 2015, 2, 79. (c) Munirathinam, R.; Huskens, J.; Verboom, W. Adv. Synth. Catal. 2015, 357, 1093. (d) RodríguezEscrich, C.; Pericàs, M. A. Eur. J. Org. Chem. 2015, 1173. Some very recent examples of continuous-flow synthetic methods: (e) Poh, J.-S.; Tran, D. N.; Battilocchio, C.; Hawkins, J. M.; Ley, S. V. Angew. Chem. Int. Ed. 2015, 54, 7920. (f) Fabry, D. C.; Ronge, M. A.; Rueping, M. Chem Eur. J. 2015, 21, 5350. (g) Tran, D. N.; Battilocchio, C.; Lou, S.-B.; Hawkins, J. M.; Ley, S. V. Chem. Sci. 2015, 6, 1120. Reviews on the synthesis of APIs under continuous-flow conditions: (h) Gutmann, B.; Cantillo, D.; Kappe, C. O. Angew. Chem. Int. Ed. 2015, 54, 6688. (i) Porta, R.; Benaglia, M.; Puglisi, A. Org. Process Res. Dev. 2016, $20,2$.

(9) For the detailed synthesis of nitroenamines, please see the Supporting Information.

(10) Brenna, D.; Porta, R.; Massolo, E.; Raimondi, L.; Benaglia, M. ChemCatChem 2017, 9, 941.

(11) Although different experimental conditions were investigated (flow rate, temperature, stoichiometry, solvents, use of additives like thiourea), the maximum yield was 33\%; low conversion and the appearance of some side products due to starting material degradation were observed and were responsible for the disappointing results.

(12) For a recent review on nitro reduction, see: Orlandi, M.; Brenna, D.; Harms, R.; Jost, S.; Benaglia, M. Org. Process Res. Dev. 2016, DOI: 10.1021/acs.oprd.6b00205.

(13) Review on continuous-flow hydrogenation: Cossar, P. J.; Hizartzidis, L.; Simone, M. I.; McCluskey, A.; Gordon, C. P. Org. Biomol. Chem. 2015, 13, 7119.

(14) (a) Orlandi, M.; Tosi, F.; Bonsignore, M.; Benaglia, M. Org. Lett. 2015, 17, 3941. (b) Orlandi, M.; Benaglia, M.; Tosi, F.; Annunziata, R.; Cozzi, F. J. Org. Chem. 2016, 81, 3037. (c) The methodology is described in a patent: Bonsignore, M.; Benaglia, M. EP 2892862, 2016.

(15) For the application of flow chemistry for multistep organic synthesis, see: (a) Newton, S.; Carter, C. F.; Pearson, C. M.; Alves, L. C.; Lange, H.; Thansandote, P.; Ley, S. V. Angew. Chem. Int. Ed. 2014, 53, 4915. (b) Wegner, J.; Ceylan, S.; Kirschning, A. Adv. Synth. Catal. 2012, 354, 17. (c) Baumann, M.; Baxendale, I. R.; Ley, S. V. Mol. Divers. 2011, 3, 613. For some other recent representative contributions, see: (d) Chen, M.; Buchwald, S. Angew. Chem. Int. Ed. 2013, 52, 4247. (e) Baxendale, I. R.; Ley, S. V.; Mansfield, A. C.; Smith, C. D. Angew. Chem. Int. Ed. 2009, 48, 4017.

(16) Yan, Q.; Liu, M.; Kong, D.; Zi, G.; Hou, G. Chem. Commun. 2014, 50,12870 . 
Synthesis

M. Pirola et al.

(17) Wang, L.; Shirakawa, S.; Maruoka, K. Angew. Chem. Int. Ed. 2011, $50,5327$.
(18) Belokon, Y. N.; Pritula, L. K.; Tararov, V. I.; Bakhmutov, V. I.; Struchknov, Y. T.; Timofeeva, T. V.; Belikov, V. M. J. Chem. Soc., Dalton Trans. 1990, 1867. 